\title{
Electromyographic parameters in abnormal gait in patients suffering from amyotrophic lateral sclerosis
}

\section{Parametry elektromiograficzne w przebiegu zaburzeń chodu u pacjentów ze stwardnieniem zanikowym bocznym}

\author{
Ilona A. Hübner1, Jacek Hübner' , Sławomir Kroczka² \\ 'Laboratory of Neurophysiology, Neurology Unit, District Hospital, Radomsko, Poland \\ Head of the Laboratory: Jacek Hübner MD \\ 2Laboratory of Neurophysiology, Department of Chair of Child and Youth Neurology, Jagiellonian University Medical College, \\ Krakow, Poland \\ Head of the Department: Prof. Marek Kaciński MD, PhD
}

Medical Studies/Studia Medyczne 2019; 35 (1): 23-31

DOI: https://doi.org/10.5114/ms.2019.84048

Key words: amyotrophic lateral sclerosis, motor unit potential, abnormal gait, electromyographic parameters. Słowa kluczowe: stwardnienie zanikowe boczne, pojedyncza jednostka ruchowa, zaburzenia chodu, parametry elektromiograficzne.

\begin{abstract}
Introduction: Amyotrophic lateral sclerosis (ALS) is a terminal neurodegenerative disease, which gradually damages motor neurons in the cortex, brainstem, and spinal cord, leading to a progressive deterioration in patients' fitness and their dependence on others.

Aim of the research: To assess electromyographic parameters and abnormal gait in the course of ALS.

Material and methods: The study covered 20 people with clinically proven or probable ALS diagnosed, determined according to the El Escorial criteria. In the study group, 10 patients were affected by the limb onset of the disorder, and the remaining 10 people by the bulbar onset. The analysis covered electromyography and test results: 6-minute walk test and 10-metre walk test performed three times within 6 months.

Results: The results of electromyographic parameters and tests were analysed for the whole group and separately for the group with bulbar-onset and limb-onset ALS. The statistical analysis of the results has shown that the duration of motor unit potential (MUP) is the most useful electromyographic parameter in early diagnosis and monitoring of the course of the disease. The increasing abnormal gait in the course of ALS was a clinical reflection of gradually prolonging MUP.

Conclusions: The progressing loss of nerve and muscle function as a result of motor neuron loss is reflected in walking deterioration in ALS patients. 2. The gradually increasing MUP duration of particular muscles is concomitant to the increasing abnormal gait. The assessment of the MUP duration of particular muscles may serve to monitor the ALS progression.
\end{abstract}

\section{Streszczenie}

Wprowadzenie: Stwardnienie zanikowe boczne (SLA) to nieuleczalna choroba neurodegeneracyjna, która uszkadza w sposób postępujący komórki ruchowe kory mózgu, pnia mózgu i rdzenia kręgowego, a także prowadzi do stopniowego pogorszenia sprawności pacjentów i ich uzależnienia od otoczenia.

Cel pracy: Ocena parametrów elektromiograficznych oraz zaburzeń chodu w przebiegu SLA.

Materiał i metody: W badaniu wzięło udział 20 osób z klinicznie pewnym lub prawdopodobnym rozpoznaniem SLA ustalonym na podstawie kryteriów El Escorial. W grupie 10 badanych osób choroba miała postać kończynową, a u pozostałych 10 - postać opuszkową. Analizie poddano wyniki badań elektromiograficznych i wyniki testów: 6-minutowego testu marszowego i 10-metrowego testu marszowego, które wykonano trzykrotnie w ciągu 6 miesięcy. Wyniki parametrów elektromiograficznych oraz testów marszowych oceniających sprawność chodu przeanalizowano dla całej badanej grupy oraz odrębnie dla chorych z postacią opuszkową i kończynową SLA.

Wyniki: Analiza statystyczna wykazała, że najbardziej przydatnym parametrem elektromiograficznym, który służy do wczesnej diagnozy oraz monitorowania przebiegu choroby, jest czas trwania pojedynczych jednostek ruchowych (MUP). Klinicznym odzwierciedleniem stopniowego wydłużania się czasu trwania MUP były narastające zaburzenia chodu w przebiegu SLA.

Wnioski: Postępujące ograniczenie funkcji nerwowo-mięśniowych wskutek utraty motoneuronów znajduje odzwierciedlenie w upośledzeniu sprawności chodu u pacjentów z SLA. Stopniowo zwiększające się wydłużenie czasu trwania MUP poszczególnych mięśni towarzyszy narastaniu zaburzeń chodu. Ocena czasu trwania MUP poszczególnych mięśni może służyć monitorowaniu postępu SLA. 


\section{Introduction}

Amyotrophic lateral sclerosis (ALS) is a progressive, terminal neurodegenerative disease leading to upper and lower motor neuron damage, namely damage of the cells located in the cerebral cortex, brain stem, and spinal cord [1-3]. The incidence rate of the sporadic form amounts on average to 1.9 per $100,000 /$ year, the frequency of approx. 7 per 100,000 in the general population. Recent years have shown an increase in the incidence rate and increased incidence rate at a younger age. The incidence rate in men is slightly higher than in women $(1.5: 1)$, but over the age of 70 years the number of men and women levels. Peak ALS incidence rate is observed at the age of 65 years; only $10 \%$ are diagnosed below the age of 45 years and $20 \%$ over 70 years [4]. The majority of ALS cases are sporadic (SALS), only $5-10 \%$ of the cases are familial (FALS), mainly inherited in an autosomal dominant manner, and with high penetration of mutation. The clinical image shows two forms: two thirds of the patients suffer from the classical form (Charcot disease) simultaneously affecting the upper and lower motor neuron; bulbar onset form; progressive muscular atrophy (PMA), which has two variants, i.e. flail arm (FA) and pseudopolyneuritic - flail leg (FL) - mainly affecting the lower motor neuron; and primary lateral sclerosis (PLS). Clinical practice uses the distinction of spinal-onset ALS, bulbar-onset ALS, and the previously mentioned flail arm and flail leg [5-7]. The diagnosis of amyotrophic lateral sclerosis is almost solely based on the clinical image supported by an electrophysiology study. Five-ten percent of the cases constitute incorrect diagnoses. Magnetic resonance imaging (MRI), cerebrospinal fluid testing (CSF) and some serological tests are performed in order to rule out other ailments that may be the reason for the upper and lower motor neuron damage [8-13]. Nowadays, the modified El Escorial criteria dating back to 1998 are used for the clinical classification of ALS [14-17]. Despite many clinical trials and progress in the understanding of ALS pathology, there are no medications effectively suppressing the development of the disease. The only medication with proven effectiveness in prolonging the ALS patients' lives is riluzole. The Food and Drug Administration (FDA) has recently approved a new drug in the treatment of ALS - edaravone - in Japan and the United States. It is an intravenous drug, whose precise mechanism of treatment of amyotrophic lateral sclerosis is not known. Edaravone may be a viable alternative after failed riluzole treatment. Regardless of the form or nature of the onset, amyotrophic lateral sclerosis always leads to gradual deterioration in physical fitness of the sufferers. The basic functions of movement, which make normal existence possible, are gradually lost. The comfort of life of ALS patients significantly worsens, they become dependent on their environment as regards activities of daily living, and finally they require specialist nutrition (percutaneous endoscopic gastrostomy - PEG, percutaneous radiologic gastrostomy - PRG, or nasogastric tube - NGT) and protective ventilation $[7,17,18]$. The average survival from the first symptoms is approx. 2-3 years for the bulbar onset and 3-5 years for the limb onset. Only approx. $5 \%$ of the patients survive more than 10 years [4].

\section{Aim of the research}

The aim of the paper was to analyse the electromyographic parameters and abnormal gait in the course of a half-year observation of ALS patients.

\section{Material and methods}

The study covered 20 patients, 5 women and 15 men, aged 43 to 85 years (on average $65.5 \pm 13$ years) with a clinically certain or possible amyotrophic lateral sclerosis diagnosis, determined on the basis of the modified El Escorial criteria [19]. The group was composed of people incidentally reporting for diagnostics, with no visible paresis, making it impossible to perform walk tests. Moreover, no patient suffered from concomitant diseases that could affect their physical fitness.

The patients were informed about the scope of the clinical trial and the electrophysiology study, to which they consented verbally. All the patients had full neurological examination panel performed along with the assessment of the upper and lower motor neuron, walk test, and electromyography.

The patients were divided into two groups, based on the clinical image: a) bulbar-onset ALS patients; b) limb-onset ALS patients.

The patients were examined three times within 6 months. The preliminary measurement was designated with the letter $\mathrm{A}$, the next one after 3 months with the letter $B$, and the last one after 6 months with the letter C.

The problem was discussed with the Bioethics Committee. In line with the arrangements, the Committee's approval to conduct the study was not required because it was of a diagnostic character and served the purpose of monitoring the course of the illness; it was not an experimental study.

The electromyographic study was carried out by the authors. In accordance with the recommendation of the Bioethical Commission, oral consent was acquired from the respondents to conduct the study and from the persons included in the control group.

Electromyography was performed with a standard method three times. The EMG test was performed using the needle method with Dantec DCN disposable concentric needle electrodes, using the Dantec Keypoint Focus equipment. Muscles from three layers of the central nervous system were subject to the procedure: the bulbus, cervical section, and the lumbosacral section of the spinal cord. The following muscles 
were subject to the procedure: muscle of the tongue $\left(12^{\text {th }}\right.$ nerve nucleus), left biceps brachii (C5-C6) (left $\mathrm{BB})$, left first dorsal interosseous muscle (C7-Th1) (left FDI), right vastus lateralis (L4-L5) (right VL), and right tibialis anterior (L5-S1) (right TA). Resting activity and the parameters of motor unit potential (MUP) were assessed in particular muscles, i.e. duration, amplitude, area, size index (SI), and polyphase potential ratio. The results of electromyographic parameters were referred to the standards of the laboratory, created on a group of 25 healthy people aged $20-80$ years (average: $51.5 \pm 32$ years). The control group were patients reporting no ailments that could affect the electrophysiological parameters.

The walk test was based on two tests: a 6-minute walk test and a 10-metre walk test [20]. The results of the tests were referred to the control group. In this case, it was a group of 20 healthy people aged 20-80 years (average: $55 \pm 28$ years), fit as regards walking. In the case of the 6-minute walk test, the higher the result, the better the movement, in the case of the 10-metre walk test, the lower the result, the better the fitness.

The results of walk tests and electromyographic parameters were analysed for the whole group and separately for the group with bulbar-onset and limbonset ALS.

\section{Statistical analysis}

The results were subject to statistical analysis with the use of descriptive methods and statistical conclusions. Arithmetic mean $(x)$ was calculated for quantity, while standard deviation was adopted as statistical dispersion. Quality features corresponding to the normal distribution were assessed with the use of the Shapiro-Wilk test and on the basis of the analysis of skewness and kurtosis and standard errors, as well as the visual assessment of histograms and Q-Q plots. Friedman two-way analysis of variance by ranks (Friedman ANOVA) was used for comparison of quantitative variables with no distribution similar to the standard one. Post hoc analyses were performed with the use of the Wilcoxon signed-rank test for dependent groups with the Bonferroni correction. The parametric analysis of variance in an intra-group scheme was applied to compare variables with distribution similar to normal. Mauchly's test was used to verify sphericity, and in the case of its lack, the Greenhouse-Geisser or Huynh-Feldt corrections were used. In this case, the Bonferroni correction was also used. Cochran's Q test was used to compare the quality variable distributions in dependent groups, while post hoc analyses were performed with the use of the McNemar's test with the Bonferroni correction. The maximum permissible type I error of $\alpha=0.05$ was adopted for all the analyses; $p \leq 0.05$ was statistically significant.

All the patients consented verbally to electromyography and walk tests for movement fitness assessment.

\section{Results}

In the course of preliminary measurement (A), as regards the standard of the laboratory, the majority of the patients had correct results as regards the duration of MUP of the right vastus lateralis (VL) (95\%) and the right tibialis anterior (TA) (85\%) as well as the right vastus lateralis polyphase potentials ratio (VL) $(90 \%)$ and the left biceps brachii (BB) (65\%). All the patients subject to analysis obtained an incorrect result as regards the amplitude, area, and size index of MUP of the left biceps brachii (BB) and the size index of MUP of the left first dorsal interosseous muscle (FDI). The majority presented incorrect results of the MUP amplitude of the left FDI muscle and the size index of MUP of the right TA muscle (95\% each) as regards the area and the duration of MUP of the left FDI muscle, the MUP amplitude, and area of the right VL muscle (90\% each) as well as concerning the duration of the left BB, the MUP amplitude, and area of the right TA muscle ( $85 \%$ each). In $80 \%$ of the cases there were incorrect values of MUP size index of the right VL muscle, while in $60 \%$ of the cases incorrect values of the polyphase potential ratio of the left FDI were obtained (Table 1). In the course of the measurement, no fasciculation was observed in the majority of subjects, i.e. in $75 \%$ in muscles of the tongue, in $65 \%$ in the left $\mathrm{BB}$, and in $60 \%$ in the right VL. In turn, active denervation potentials were recorded in all the patients (these were fibrillation or positive sharp waves) in the muscles of the tongue and in the majority in the left FDI muscle (95\%), the right TA (85\%), and the left $\mathrm{BB}$ and right VL (65\% each).

The analysis of walk tests results revealed abnormalities in $85 \%$ of the patients in the case of the 6 -minute walk test and in $80 \%$ in the 10 -metre walk test.

The analysis of electromyographic parameters within half a year in the studied group has shown statistically significant differences between particular measurements as regards the duration of the motor unit potential (MUP) of the left $\mathrm{BB}$, left FDI, right TA, and right VL as regards the MUP amplitude of the right TA, right $\mathrm{VL}$, and polyphase potential ratio of the left FDI.

Two-way analyses have shown that the duration of MUP of the left BB in patients in the course of the A measurement was lower than in the B measurement $(p=0.001)$ and the $C$ measurement $(p<0.001)$, the duration of MUP of the left FDI in the course of the A measurement was lower than in the course of the B measurement $(p<0.001)$ and the $\mathrm{C}$ measurement $(p=0.004)$, the duration of MUP of the right TA in the course of the A measurement was lower than in the course of the B measurement $(p=0.001)$ and the $\mathrm{C}$ measurement $(p=0.031)$, and the duration of MUP of the right VL in the course of the A measurement was lower than in the case of the B measurement $(p=0.001)$ and $\mathrm{C}$ measurement $(p=0.011)$ (Figure 1). Moreover, the analyses showed that the multiphase 
Table 1. Structure of motor unit potential parameters in the course of preliminary measurement and within 6 months in the studied group $(N=20)$

\begin{tabular}{|c|c|c|c|c|c|c|c|}
\hline \multirow[t]{2}{*}{ Muscle } & \multirow{2}{*}{$\begin{array}{l}\text { Parameter } \\
\text { MUP }\end{array}$} & \multirow{2}{*}{$\begin{array}{l}\text { Measurement } \\
\text { moment }\end{array}$} & \multicolumn{2}{|c|}{ Abnormal value } & \multirow[t]{2}{*}{$N$} & \multirow[t]{2}{*}{ Mean } & \multirow[t]{2}{*}{ SD } \\
\hline & & & $N$ & $\%$ of total & & & \\
\hline \multirow{15}{*}{$\begin{array}{l}\text { Left biceps } \\
\text { brachii (BB) }\end{array}$} & \multirow[t]{3}{*}{ Amplitude $[\mu \mathrm{V}]$} & A & 20 & 100.00 & 20 & 1011.05 & 279.60 \\
\hline & & B & 20 & 100.00 & 20 & 997.55 & 312.29 \\
\hline & & C & 20 & 100.00 & 20 & 1017.10 & 304.27 \\
\hline & \multirow[t]{3}{*}{ Area $[\mathrm{ms} / \mu \mathrm{V}]$} & A & 20 & 100.00 & 20 & 1124.71 & 1124.71 \\
\hline & & B & 19 & 95.00 & 20 & 1831.90 & 1136.86 \\
\hline & & C & 20 & 100.00 & 20 & 2038.40 & 1243.73 \\
\hline & \multirow[t]{3}{*}{ Duration [ms] } & $A$ & 17 & 85.00 & 20 & 13.17 & 1.30 \\
\hline & & B & 20 & 100.00 & 20 & 14.25 & 0.96 \\
\hline & & $C$ & 19 & 95.00 & 20 & 14.24 & 1.29 \\
\hline & \multirow[t]{3}{*}{ Size Index (SI) } & $A$ & 20 & 100.00 & 20 & 1.61 & 0.33 \\
\hline & & B & 19 & 95.00 & 20 & 1.57 & 0.40 \\
\hline & & C & 20 & 100.00 & 20 & 1.65 & 0.47 \\
\hline & \multirow{3}{*}{$\begin{array}{c}\text { Polyphase } \\
\text { potentials (\%) }\end{array}$} & A & 7 & 35.00 & 20 & 14.71 & 8.31 \\
\hline & & B & 11 & 55.00 & 20 & 18.37 & 10.58 \\
\hline & & C & 9 & 45.00 & 20 & 17.63 & 10.98 \\
\hline \multirow{15}{*}{$\begin{array}{l}\text { Left first } \\
\text { dorsal } \\
\text { interosseous } \\
\text { (FDI) }\end{array}$} & \multirow[t]{3}{*}{ Amplitude $[\mu \mathrm{V}]$} & $A$ & 19 & 95.00 & 20 & 1686.10 & 1200.56 \\
\hline & & B & 17 & 85.00 & 20 & 2179.30 & 2540.93 \\
\hline & & C & 18 & 90.00 & 20 & 1658.85 & 1210.53 \\
\hline & \multirow[t]{3}{*}{ Area $[\mathrm{ms} / \mu \mathrm{V}]$} & A & 18 & 90.00 & 20 & 2791.25 & 2260.86 \\
\hline & & B & 16 & 80.00 & 20 & 2955.40 & 2320.96 \\
\hline & & C & 19 & 95.00 & 20 & 2999.10 & 2373.55 \\
\hline & \multirow[t]{3}{*}{ Duration [ms] } & $A$ & 18 & 90.00 & 20 & 13.13 & 1.13 \\
\hline & & B & 19 & 95.00 & 20 & 13.91 & 0.98 \\
\hline & & C & 19 & 95.00 & 20 & 13.81 & 1.12 \\
\hline & \multirow[t]{3}{*}{ Size Index (SI) } & A & 20 & 100.00 & 20 & 1.85 & 0.25 \\
\hline & & B & 18 & 90.00 & 20 & 1.89 & 0.39 \\
\hline & & $\mathrm{C}$ & 20 & 100.00 & 20 & 1.86 & 0.24 \\
\hline & \multirow{3}{*}{$\begin{array}{c}\text { Polyphase } \\
\text { potentials (\%) }\end{array}$} & $A$ & 12 & 60.00 & 20 & 21.25 & 9.62 \\
\hline & & B & 16 & 80.00 & 20 & 23.14 & 10.42 \\
\hline & & C & 18 & 90.00 & 20 & 30.50 & 13.39 \\
\hline \multirow{6}{*}{$\begin{array}{l}\text { Right tibialis } \\
\text { anterior (TA) }\end{array}$} & \multirow[t]{3}{*}{ Amplitude $[\mu \mathrm{V}]$} & $\mathrm{A}$ & 17 & 85.00 & 20 & 1213.15 & 279.81 \\
\hline & & $B$ & 13 & 65.00 & 20 & 1263.75 & 354.65 \\
\hline & & C & 17 & 85.00 & 20 & 1338.20 & 279.64 \\
\hline & \multirow[t]{3}{*}{ Area $[\mathrm{ms} / \mu \mathrm{V}]$} & A & 17 & 85.00 & 20 & 2341.20 & 684.50 \\
\hline & & B & 14 & 70.00 & 20 & 2359.90 & 913.44 \\
\hline & & C & 19 & 95.00 & 20 & 2565.25 & 1072.60 \\
\hline
\end{tabular}


Table 1. Cont.

\begin{tabular}{|c|c|c|c|c|c|c|c|}
\hline \multirow[t]{2}{*}{ Muscle } & \multirow{2}{*}{$\begin{array}{l}\text { Parameter } \\
\text { MUP }\end{array}$} & \multirow{2}{*}{$\begin{array}{l}\text { Measurement } \\
\text { moment }\end{array}$} & \multicolumn{2}{|c|}{ Abnormal value } & \multirow[t]{2}{*}{$N$} & \multirow[t]{2}{*}{ Mean } & \multirow[t]{2}{*}{ SD } \\
\hline & & & $N$ & $\%$ of total & & & \\
\hline & \multirow[t]{3}{*}{ Duration [ms] } & A & 3 & 15.00 & 20 & 13.46 & 1.20 \\
\hline & & B & 5 & 25.00 & 20 & 14.60 & 1.55 \\
\hline & & C & 5 & 25.00 & 20 & 14.10 & 1.25 \\
\hline & \multirow[t]{3}{*}{ Size Index (SI) } & A & 19 & 95.00 & 20 & 1.99 & 0.37 \\
\hline & & B & 18 & 90.00 & 20 & 2.01 & 0.41 \\
\hline & & C & 18 & 90.00 & 20 & 2.02 & 0.48 \\
\hline & \multirow{3}{*}{$\begin{array}{c}\text { Polyphase } \\
\text { potentials (\%) }\end{array}$} & A & 8 & 40.00 & 20 & 16.35 & 13.23 \\
\hline & & $\mathrm{B}$ & 11 & 55.00 & 20 & 18.82 & 10.64 \\
\hline & & $\mathrm{C}$ & 12 & 60.00 & 20 & 19.92 & 11.91 \\
\hline \multirow{15}{*}{$\begin{array}{l}\text { Right vastus } \\
\text { lateralis (VL) }\end{array}$} & \multirow[t]{3}{*}{ Amplitude $[\mu \mathrm{V}]$} & A & 18 & 90.00 & 20 & 1219.35 & 241.28 \\
\hline & & B & 17 & 85.00 & 20 & 1226.20 & 261.25 \\
\hline & & C & 19 & 95.00 & 20 & 1323.95 & 256.20 \\
\hline & \multirow[t]{3}{*}{ Area $[\mathrm{ms} / \mu \mathrm{V}]$} & A & 18 & 90.00 & 20 & 2282.90 & 507.21 \\
\hline & & $\mathrm{B}$ & 17 & 85.00 & 20 & 2418.50 & 758.86 \\
\hline & & C & 17 & 85.00 & 20 & 2611.50 & 726.37 \\
\hline & \multirow[t]{3}{*}{ Duration [ms] } & A & 1 & 5.00 & 20 & 13.82 & 0.84 \\
\hline & & B & 7 & 35.00 & 20 & 14.71 & 1.09 \\
\hline & & C & 7 & 35.00 & 20 & 14.37 & 1.20 \\
\hline & \multirow[t]{3}{*}{ Size Index (SI) } & A & 16 & 80.00 & 20 & 1.90 & 0.29 \\
\hline & & $\mathrm{B}$ & 18 & 90.00 & 20 & 1.99 & 0.36 \\
\hline & & $\mathrm{C}$ & 19 & 95.00 & 20 & 2.00 & 0.32 \\
\hline & \multirow{3}{*}{$\begin{array}{c}\text { Polyphase } \\
\text { potentials (\%) }\end{array}$} & A & 2 & 10.00 & 20 & 10.45 & 4.97 \\
\hline & & B & 6 & 30.00 & 20 & 13.36 & 9.44 \\
\hline & & C & 4 & 20.00 & 20 & 12.23 & 4.71 \\
\hline
\end{tabular}

MUP - motor unit potential, $N$ - number, SD - standard deviation. Measurement moment: $A$ - initial measurement, $B$ - measurement after 3 months, $C$ - measurement after 6 months.

potentials ratio of the left FDI muscle in the course of the A measurement was lower than in the B and C measurement ( $p=0.032$ ), and the MUP amplitude of the right TA in the course of the A measurement was lower than in the case of the $\mathrm{B}$ and $\mathrm{C}$ measurement $(p=0.032)$, and the MUP amplitude of the right VL was lower in the A measurement than in the B and C measurement $(p=0.032)$.

As regards the remaining MUP parameters of the muscles subjected to testing, analyses showed no statistically significant differences between particular measurement $(p>0.05)$.

Analysis as regards the potentials of active and chronic denervation in all the muscles subjected to examination presented no statistically significant differences in the course of the 6-month observation of patients $(p>0.05)$.
The analysis of walk tests within half a year showed that the result of the 10-metre walk test in the course of the A measurement was lower than in the case of the B measurement $(p<0.001)$ and C measurement ( $p=0.001)$. In turn, the result of the 6-minute walk test during the A measurement was higher than in the case of the B measurement $(p<0.001)$ and the $\mathrm{C}$ measurement $(p<0.001)$ (Figures 2 and 3$)$.

The assessment of electromyographic parameters in case of the ALS limb onset presented statistically significant differences between particular measurements as regards the duration of MUP of the left BB, left FDI, right VL, and MUP area of the right VL. Comparisons performed multiple times have shown that the duration of MUP of the left BB in the course of the preliminary A measurement was lower than in the course of the B and C measurement ( $p=0.021$ ); of the 


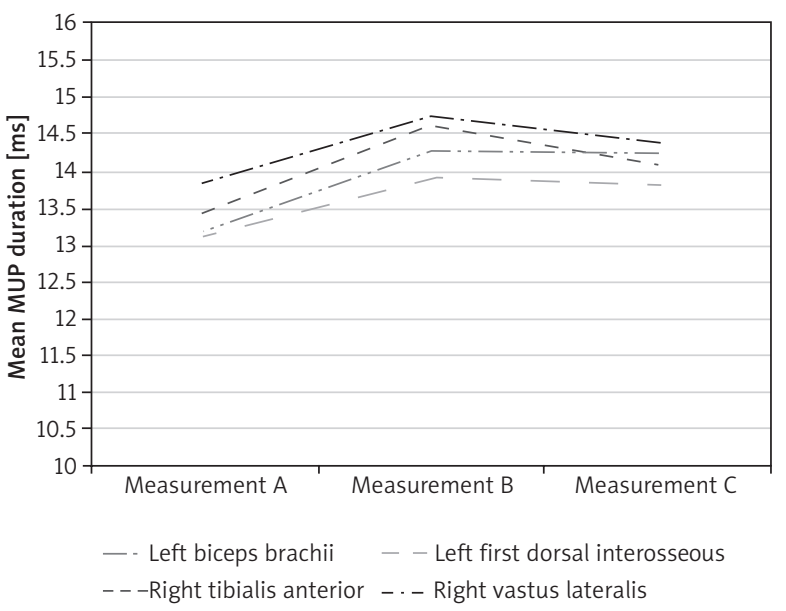

Figure 1. Mean duration of MUP, left BB, left FDI, right TA, and right VL in the studied group within 6 months

Measurements: A - initial, B - after 3 months, $C$-after 6 months.

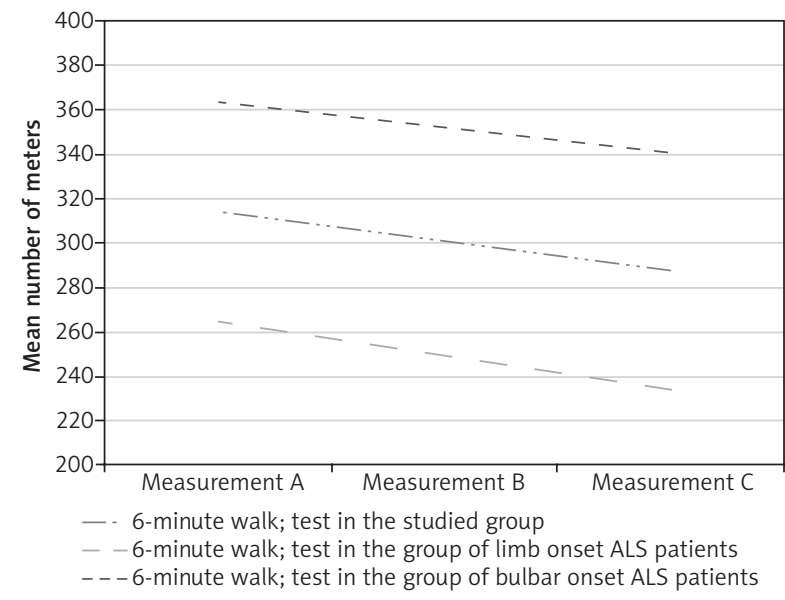

Figure 3. Mean results of the 6-minute walk test within 6 months in the studied group, in the case of limb-onset ALS patients and bulbar-onset ALS patients

left FDI in the course of the A measurement was lower than in the case of the B measurement $(p=0.015)$ and during the $\mathrm{C}$ measurement ( $p=0.043$ ); of the right VL in the course of the A measurement was lower than in the case of the B measurement $(p=0.028)$ and in the course of the $\mathrm{C}$ measurement ( $p=0.015)$, and the area of MUP of the right VL in the course of the A measurement was lower than in the case of the B and C measurements ( $p=0.038$ ) (Figure 4$)$. The remaining electromyographic parameters showed no statistically significant differences in the course of the half-year observation of limb-onset ALS patients. The analysis of walk tests results in the patients presented - as in the assessment of all the patients subject to testing statistically significant differences, i.e. as regards the 10 -metre walk test the result in the A measurement was lower than in the B measurement $(p<0.001)$, and during the $\mathrm{B}$ measurement it was lower than in the

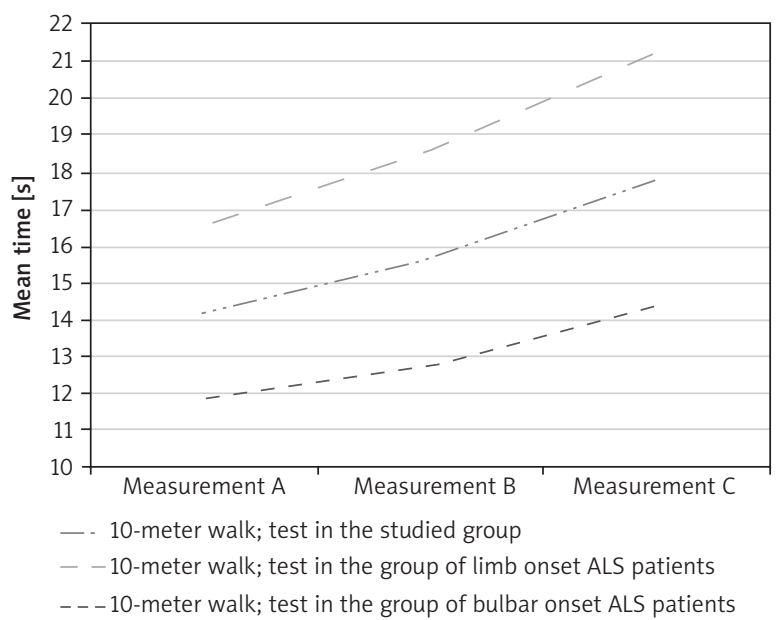

Figure 2. Mean result of the 10-metre walk test within 6 months in the studied group, in patients with limb-onset ALS and bulbar-onset ALS

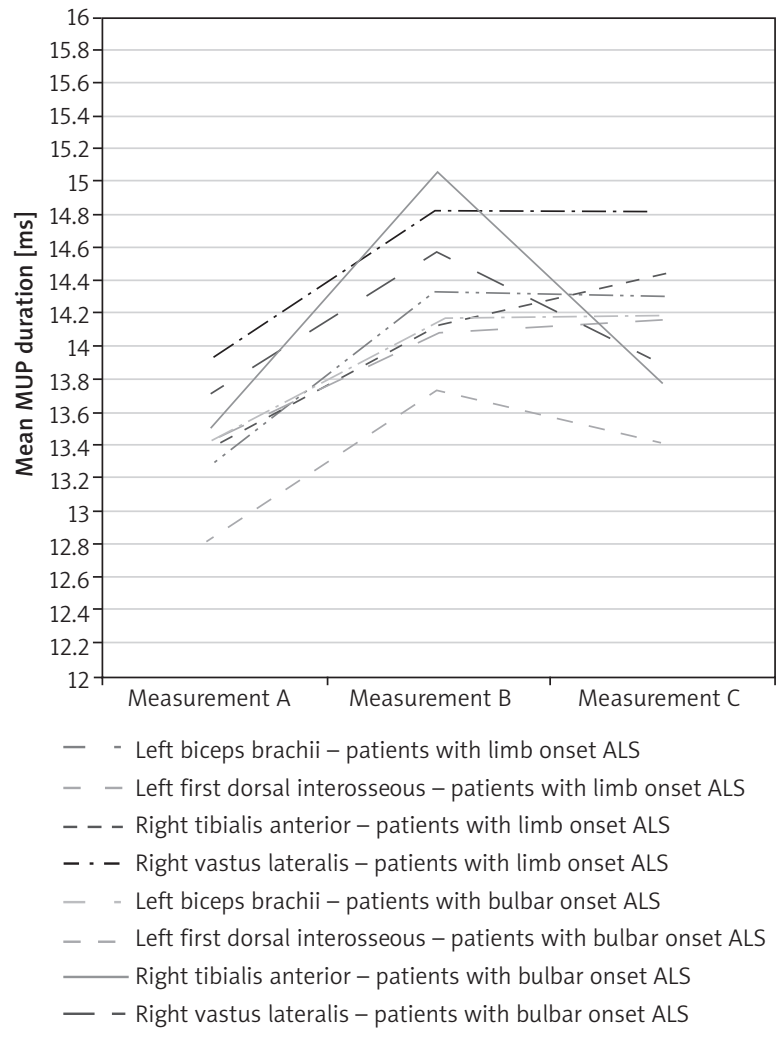

Figure 4. Mean MUP duration of the studied muscles within 6 months in limb-onset ALS patients and bulbar-onset ALS patients

C measurement $(p<0.001)$; as regards the 6-minute walk test the result was higher in the A measurement than in the B measurement $(p=0.001)$ and in the $\mathrm{B}$ measurement it was higher than in the $C$ measurement $(p<0.001)$ (Figures 2 and 3). There were no significant differences between the measurements as 
regards the presence of denervation potentials in all the muscles subject to testing $(p>0.05)$.

The same analysis in the bulbar-onset ALS patient group showed statistically significant differences as regards the duration of MUP of the left BB, left FDI, right TA, right VL, as well as the MUP area of the left $\mathrm{BB}$ and MUP amplitude of the right TA. Multiple comparisons have shown that the duration of MUP of the left BB in the course of the A measurement was lower than in the case of the B measurement $(p=0.021)$ and in the course of the $\mathrm{C}$ measurement $(p=0.021)$; of the left FDI was lower in the case of the A measurement than in the course of the B measurement $(p=0.024)$; of the right TA in the course of the $\mathrm{B}$ measurement was higher than in the course of the A measurement $(p=0.027)$ and the course of the $\mathrm{C}$ measurement ( $p=0.035$ ); of the right VL in the course of the A measurement was lower than in the course of the B measurement ( $p=0.021)$ (Figure 4). Moreover, the MUP area of the left $\mathrm{BB}$ in the course of the A measurement was higher than in the course of the $\mathrm{B}$ measurement $(p=0.021)$ and the MUP amplitude of the right TA in the course of the A measurement was lower than in the course of the $\mathrm{B}$ and $\mathrm{C}$ measurement ( $p=0.005)$. The remaining parameters indicated no statistically significant differences in the course of the subsequent measurements. Also in this case, the analysis of walk tests results within half a year showed significant differences, i.e. as regards the 10-metre walk test the results in the A measurement were lower than in the B measurement ( $p=0.012)$ and in the B measurement it was lower than in the $\mathrm{C}$ measurement $(p=0.003)$, and as regards the 6 -minute walk test the result of the A measurement was higher than in the B measurement ( $p=0.023)$ and in the course of the B measurement it was higher than in the $\mathrm{C}$ measurement $(p=0.001)$ (Figurs 2 and 3). Moreover, in the case of bulbar-onset ALS patients there were no statistically significant differences observed as regards the denervation potentials between the measurements.

\section{Discussion}

In the case of ALS patients, the most common abnormalities observed upon electromyography are a record of neurogenic damage nature. The record has the features of active denervation and reinnervation. The features of acute denervation include fibrillation at rest and positive free waves, while the features of reinnervation include an increase in the motor unit potential parameters (MUP). The ALS-specific fasciculations at rest are also present.

While analysing their own study, the authors demonstrated fibrillation at rest and positive free waves in the course of preliminary assessment in the majority of patients, while fasciculation was observed far less frequently. The motor unit potential of the examined muscles presented increased amplitude, area, size in- dex, and duration. The results are similar to the findings of Ren et al. [21] and Xu et al. [22].

Benaim et al. used multiple function scales to clinically assess the fitness of ALS patients; most often they applied the ALS functional rating scale (ALSFRS) [23]. Our studies utilised completely different tests to perform the walk test, namely a 6-minute walk test and a 10-metre walk test. Lorenz et al. monitored the progress of rehabilitation of patients with incomplete spinal cord injury with the use of the tests we applied [20].

Amyotrophic lateral sclerosis naturally leads to the imminent loss of nerve and muscle function, which clinically leads to amyotrophy or paresis, which deteriorate the physical fitness of the patients [24]. As the disease progresses, the patients become less and less fit, they rely on the help of the family, and finally they die shortly afterwards [1]. The results we have obtained show that in the case of the majority of patients, abnormalities as regards the clinical tests correspond to the results of neurophysiological testing, which proves earlier findings.

Wijesekera et al. wrote that amyotrophy and muscle paresis are of progressive nature within the course of the disease, and as a result they lead to a gradual increase in abnormal gait [4]. These findings correspond to ours.

Couratier et al. found that the loss of motor functions is inevitable in the case of ALS patients, it leads to deterioration in their fitness, and as the disease progresses - to severe disability and the patient becoming dependent on the environment even in simple activities of daily living. They used multiple scales to monitor the progress of the dysfunction, i.e. the ALS functional rating scale, ALS severity scale, Appel scale, Norris scale, and Honda scale [18]. The authors obtained similar results as those mentioned above using completely different tests for disease progress monitoring.

According to de Carvalho et al., electromyography as well as nerve conduction and MUNE are used to monitor the disease progression [25]. Higashihara and Sonoo used the analysis of the resting record and MUP to diagnose and assess the course of ALS [26]. In our studies, we used the aforementioned electromyography as well as clinical testing. Banach and Rakowicz used the same electromyography as the authors for preliminary diagnosis of ALS and MUNE, to assess the disease progression [11].

In our own studies, we showed the statistically significant prolonged duration of MUP of the muscles subjected to testing in the course of the half-year observation. The analysis of the results is consistent with the remarks of de Carvalho et al., who deemed that the duration of MUP is the best reinnervation indicator at the early stage of the disease and most often shows variability in the disease course from among all the MUP parameters [27]. Jacobsen et al. consider the MUNE methods as more sensitive than the assess- 
ment of MUP duration to diagnose and monitor nerve and muscle disorders in ALS patients [28].

The assessment of denervation potentials showed no significant differences within the period of 6 months in our studies.

de Carvalho et al. found that in the case of some patients with serious atrophy of first dorsal interosseous muscles, the incidence rate of fasciculation was increasing as the disease progressed [29].

The analysis of test results showed significant intensification in abnormal gait in the course of the half-year observation, which is reflected in the results of the 6-metre walk test and the 10-minute walk test.

The results of the electrophysiology studies obtained in the course of $\mathrm{A}, \mathrm{B}$, and $\mathrm{C}$ measurements, especially the gradually prolonging duration of MUP, were reflected in the abnormal gait of the patients.

Jawdat et al. showed in their paper that in the case of bulbar-onset ALS patients, the disease progresses much faster and is more visible [2]. We showed in our analyses a significant deterioration in the electromyographic parameters and clinical tests in the course of a 6-month observation in a similar manner in both groups, namely patients with bulbar- and limb-onset ALS. These results do not confirm the earlier findings.

The authors wish to emphasise that the assessment of MUP duration of particular muscles may be beneficial for monitoring the ALS progression.

\section{Conclusions}

The progressing loss of nerve and muscle function as a result of motor neuron loss is reflected in walking deterioration in ALS patients. The gradually increasing MUP duration of particular muscles is concomitant to the increasing abnormal gait. The assessment of the MUP duration of particular muscles may serve to monitor the ALS progression.

\section{Conflict of interest}

The authors declare no conflict of interest.

\section{References}

1. Westeneng HJ, Debray TPA, Visser AE, van Eijk RPA, Rooney JPK, Calvo A, Martin S, McDermott CJ , Thompson AG, Pinto S, Kobeleva X, Rosenbohm A, Stubendorff B, Sommer H, Middelkoop BM, Dekker AM, van Vugt JJFA, van Rheenen W, Vajda A, Heverin M, Kazoka M, Hollinger $\mathrm{H}$, Gromicho M, Körner S, Ringer TM, Rödiger A, Gunkel A, Shaw CE, Bredenoord AL, van Es MA, Corcia P, Couratier P, Weber M, Grosskreutz J, Ludolph AC, Petri S, de Carvalho M, Van Damme P, Talbot K, Turner MR, Shaw PJ, Al-Chalabi A, Chio A, Hariman O, Moons KGM, Veldink JH, van den Berg LH. Prognosis for patients with amyotrophic lateral sclerosis: development and validation of a personalised prediction model. Lancet Neurol 2018; 17: 423-433.

2. Jawdat O, Statland JM, Barohn RJ, Katz JS, Dimachkie MM. Amyotrophic lateral sclerosis regional variants (brachial amyotrophic diplegia, leg amyotrophic diplegia, and isolated bulbar amyotrophic lateral sclerosis). Neurol Clin 2015; 33: 775-785

3. Turner MR, Hardiman O, Brooks BR, Chio A, de Carvalho M, Ince PG, Lin C, Miller RG, Mitsumoto H, Nicholson G, Ravits J, Show PJ, Swash M, Talbot K, Traynor BJ, Van den Berg LH, Veldink JH, Vucic S, Kiernan MC. Controversies and priorities in amyotrophic lateral sclerosis. Lancet 2013; 12: 310-322.

4. Wijesekera LC, Leigh PN. Amyotrophic lateral sclerosis. Orphanet J Rare Dis 2009; 4: 3 .

5. Gale C. Assisting patients with motor neurone disease to make decisions about their care. Int J Palliat Nurs 2015; 21: 251-255.

6. Mitchell JD, Borasio GD. Amyotrophic lateral sclerosis. Lancet 2007; 369: 2031-2041.

7. Bäumer D, Talbot K, Turner MR. Advances in motor neuron disease. J R Soc Med 2014; 107: 14-21.

8. Ferguson TA, Elman LB. Clinical presentation and diagnosis of amyotrophic lateral sclerosis. Neurorehabilitation 2007; 22: 409-416.

9. de Carvalho M, Johnsen B, Fuqlsanq-Frideriksen A. Medical technology assessment. Electrodiagnosis in motor neuron diseases and amyotrophic lateral sclerosis. Neurophysiol Clin 2001; 31: 341-348.

10. Lenglet T, Camolessanche JP. Amyotrophic lateral sclerosis or not: keys for the diagnosis. Rev Neurol (Paris) 2017; 173: 280-287.

11. Banach M, Rakowicz M. Electrophysiological diagnosis of amyotrophic lateral sclerosis. Przegl Lek 2010; 67: 736740.

12. Vial C. What are the clinical criteria of amyotrophic lateral sclerosis by clinical form? Rev Neurol (Paris) 2006; 162: 4S25-4S28.

13. Duleep A, Shefner J. Electrodiagnosis of motor neuron disease. Phys Med Rehabil Clin N Am 2013; 24: 139-151.

14. Joyce NC, Carter GT. Electrodiagnosis in persons with amyotrophic lateral sclerosis. PMR 2013; 5 (Suppl 1): 89-95.

15. Inghilleri M, Iacovelli E. Clinical neurophysiology in ALS, Arch Ital Biol 2011; 149: 57-63.

16. Boekestein WA, Kleine BU, Hageman G, Schelhaas HJ, Zwarts MJ. Sensitivity and specificity of the 'Awaji' electrodiagnostic criteria for amyotrophic lateral sclerosis: retrospective comparison of the Awaji and revised El Escorial criteria for ALS. Amyotroph Lateral Scler 2010; 11: 497-501.

17. Jensen L, Djurtoft JB, Bech RD, Nielsen JL, Jorgense LH, Schroder HD, Frandsen U, Aaqaard P, Hvid LG. Influence of resistance training on neuromuscular function and physical capacity in ALS patients. J Neurodegener Dis 2017; 2017: 1436519.

18. Couratier P, Torny F, Lacoste M. Functional rating scales for amyotrophic lateral sclerosis. Rev Neurol (Paris) 2006; 162: 502-507.

19. Brooks BR, Miller RG, Swash M, Munsat TL. World Federation of Neurology Research Group on Motor Neuron Diseases. El Escorial revisited: revised criteria for the diagnosis of amyotrophic lateral sclerosis. Amyotroph Lateral Scler Other Motor Neuron Disord 2000; 1: 293-299.

20. Lorenz DJ, Datta S, Harkema SJ. Longitudinal patterns of functional recovery in patients with incomplete spinal 
cord injury receiving activity-based rehabilitation. Arch Phys Med Rehabil 2012; 93: 1541-1552.

21. Ren YT, Cui F, Yang F, Chen ZH, Ling L, Huang XS. Needle electromyography features and value of paraspinal muscle parameters in assessment of respiratory function of patients with amyotrophic lateral sclerosis. Zhonghua Yi Xue Za Zhi 2016; 96: 2616-2619.

22. Xu Y, Zheng J, Zhang S, Kang D, Zhang J, Fan D. Needle electromyography of the rectus abdominis in patients with amyotrophic lateral sclerosis. Muscle Nerve 2007; 35: 383-385

23. Benaim C, Desnuelle C, Fournier-Mehouas M. Functional scales and motor assessment in amyotrophic lateral sclerosis. Rev Neurol (Paris) 2006; 162: 4S131-4S137.

24. Murray L, Butow PN. Advance care planning in motor neuron disease: a systematic review. Palliat Support Care 2016; 14: 411-432.

25. de Carvalho M, Chio A, Dengler R, Hecht M, Weber M, Swash M. Neurophysiological measures in amyotrophic lateral sclerosis: markers of progression in clinical trials. Amyotroph Lateral Scler Other Motor Neuron Disord 2005; 6: 17-28.

26. Higashihara M, Sonoo M. Electrodiagnosis of ALS. Brain Nerve 2007; 59: 1031-1041.

27. de Carvalho M, Turkman A, Swash M. Sensitivity of MUP parameters in detecting change in early ALS. Clin Neurophysiol 2014; 125: 166-169.

28. Jacobsen AB, Kristensen RS, Witt A, Kristense AG, Duez L, Beniczky S, Fuglsang-Frederiksen A, Tankisi H. The utility of motor unit number estimation methodes versus quantitative motor unit potential analysis in diagnosis of ALS. Clin Neurophysiol 2018; 129: 646-653.

29. de Carvalho M, Swash M. Fasciculation discharge frequency in amyotrophic lateralizacji sclerosis and related disorders. Clin Neurophysiol 2016; 127: 2257-2262.

\section{Address for correspondence:}

\section{Ilona Hübner}

Department of Neurology

District Hospital

ul. Jagiellońska 36, 97-500 Radomsko, Poland

Phone: +48 608585230

E-mail: dymiatko@op.pl 